\title{
IMPLEMENTASI TUGAS DAN FUNGSI ARSIPARIS SEBAGAI PENGELOLA ARSIP DI LEMBAGA ARSIP NASIONAL REPUBLIK INDONESIA
}

\author{
Wiwin Irpina \\ Pascasarjana UIN Sunan Kalijaga Yogyakarta \\ e-mail: 20200011048@student.uin-suka.ac.id
}

\begin{abstract}
This study uses a qualitative method with a naturalistic approach to determine the duties and functions of archivists at the National Archives Institute of the Republic of Indonesia. Data collection is done through literature study, both primary and secondary data so as to be able to clarify various things found in qualitative research. Furthermore, the data analysis techniques used is a contents analysis technique where the data analysis process begins before and during the data search process through the online website of the National Archives of the Republic of Indonesia which is then poured in the form of descriptive narratives and inductively summarizes the core. The duties and functions of archivists in carrying out work are reviewed in the perspective of Article 151 offthe Governmentt Regulation of the Republic of Indonesia Number 28 of 2012 concerning the Implementation of Law Number 43 of 2009 concerning Archives. The results show that the duties and functions of archivists at the National Archives of the Republic of Indonesia have been implemented as stated in Article 151 of the Government Regulation of the Republic of Indonesia Number 28 of 2012 concerning the Implementation of Law Number 43 of 2009 concerning Archives. The researcher recommends that the head of the National Archives of the Republic of Indonesia continue to provide guidance and development of archival human resources, one of which is through training, work motivation, application of quality standards of archivist work based on the duties, functions and responsibilities of archivists so that they can make archives as a unifying node of the nation in the framework of the Unitary State of the Republic of Indonesia which is managed by professional and reliable archivists.
\end{abstract}

Keywords: Duties And Functions Of Archives, National Archives of The Republic Of Indonesia. 


\section{PENDAHULUAN}

Arsip yang tercipta merupakan bukti dari suatu aktivitas dari suatu organisasi atau individu dalam menjalankan fungsi dan tugas pokoknya atau hubungan yang pernah terjalin antara organisasi dengan pihak lain dan merupakan sumber informasi mengenai orang, organisasi, peristiwa, dan tempat-tempat tertentu. Sebagai suatu tempat, setiap arsip yang disimpan dirancang untuk memenuhi beberapa kebutuhan. Salah satunya kebutuhan untuk mendapatkan dan memanfaatkan informasi. Informasi yang mampu memberikan gambaran objektif tentang suatu peristiwa atau keadaan di masa lalu, saat ini, dan di masa depan, baik untuk kepentingannya sendiri maupun untuk kepentingan orang banyak. Informasi yang dibuat oleh manusia maupun badan korporasi (kementerian, instansi, perusahaan, organisasi, yayasan, dan sejenisnya) ini merupakan informasi yang terekam dalam segala bentuk dan media sejalan dengan perkembangan teknologi informasi dan komunikasi, atau sering dikenal dengan sebutan arsip.

Dalam Undang-Undang Nomor 43 Tahun 2009 tentang kearsipan mengatur bahwa pengolahan arsip statis dalam rangka penyelenggaran kearsipan nasional dilaksanakan oleh lembaga kearsipan terhadap kearsipan statis dalam.

Berbagai bentuk dan media sama dengan perkembangan teknologi informasi komunikasi. Kegiatan pengolahan kearsipan statis sesuai dengan kewewenangan lembaga arsip tersebut, meliputi: akuisisi, pengolahan, preservasi, dan akses arsip statis. Salah satu lembaga yang memiliki wewenang dalam pengolah arsip statis yang merupakan lembaga milik pemerintah yaitu Arsip Nasional Republik Indonesia atau yang lebih tenar dengan sebutan ANRI.

Lembaga kearsipan di Indonesia yang beralamat di J1. Ampera Raya No. 7 RT. 3/RW.4, Kecamatan Ps. Minggu, Kota Jakarta Selatan, Ibukota Jakarta, 12560. Lembaga Arsip Nasional Indonesia berdiri pada tahun 
1892 ketika pemerintah Hindia Belanda mendirikan sebuah Landarchief yang bertangung jawab memelihara arsip-arsip pada masa VOC hingga masa pemerintahan hindia belanda untuk kepentingan administrasi dan ilmu pengetahuan, serta membantu melancarkan pelaksanaan pemerintah pada masa itu. Sejak tahun 1942 hingga tahun 1967 Lembaga Arsip Nasional Republik Indonesia sudah Tujuh kali berganti nama dan sudah Sembilan kali berganti kepemimpinan di lembaga Arsip Nasional Republik Indonesia. Dalam pengolahan kearsipan dan peningkatan kualitas Sumber Daya Manusia (SDM) Lembaga Arsip Nasional Republik Indonesia senantiasa memberikan berbagai pelatihan untuk dapat meningkatkan pengetahuan, skill, dan motivasi bagi para arsiparis sehingga bisa memberikan pengabdian serta pelayanan yang terbaik kepada masyarakat sesuai dengan tugas dan fungsi Lembaga Arsip Nasional Republik Indonesia. Dalam pengolahan arsip sangat di dukung oleh tenaga arsiparis yang professional dalam melakukan pengolahan arsip yang sesuai dengan tugas, fungsi arsiparis.

Tulisan kajian ini bermaksud mendeskripsikan, fungsi, tugas, dan kewenangan Arsiparis yang tercantum dalam Pasal 151 ayat (2) dan Pasal 152 Peraturan Pemerintahh Nomor 28 Tahun 2012 tentang "Pelaksanaan Undang-Undang Nomor 43 Tahun 2009 tentang Kearsipan dengan tugas pokok Arsiparis yang tertuang dalam Pasal 8 Peraturan Menteri Negara Pendayagunaan Aparatur Negara". Berdasarkan penjelasan, latar belakang dan permasalahan sebelumnya maka tujuan kajian ini adalah ingin mengetahui implementasi tugas, fungsi, dan kewenangan yang dimiliki Arsiparis dalam menjalankan tugasnya. Adapun manfaat dari kajian ini adalah menjadi bahan masukan untuk membina dan mengembangkan jabatan fungsional Arsiparis yang berrkualitas dan professional kearah peningkatan kualitas arsiparis di lembaga Arsip Nasional Republik Indonesia. 


\section{METODE PENELITIAN}

Jenis penelitian ini termasuk penelitian, kualitatif yang mencoba mendeskripsikan tentang gejala yang terjadi pada objek sesuai fokus permasalahan (Sugiyono, 2016). Pendekatan penelitian ini menggunakan pendekatan naturalistic untuk menelitii kondisi objek yangn alami (Lexxy, 2019) yaitu tugas, fungsi, dan kewenangan Arsiparis. Pengumpulan data dilakukan melalui studi pustaka, baik data primer dan sekunder sehingga mampu memperjelaskan berbagai hal yang ditemukan dalam penelitian kualitatif. Selanjutnya, teknik analisis data yang digunakaan adalah teknik analisis isi (content analysis) dimana proses analisis data dimulai sejak sebelum dan selama proses pencarian data melalui website online yang kemudian dituangkan dalam bentuk narasi deskriptif dan membuat rangkuman inti secara induktif.

\section{PEMBAHASAN/PENGERTIAN ARSIP}

Barthos (2012: 1) mendefinisikan arsip (record) yang dalam istilah bahasa Indonesia ada yang menyebutkan sebagai "warkat", pada pokoknya dapat diberikan pengertian sebagai: setiap catatan tertulis baik dalam bentuk gambar ataupun bagan yang memuat keterangan-keterangan mengenai sesuai subyek (pokok persoalan) ataupun peristiwa yang dibuat orang untuk membantu daya ingatan orang (itu) pula.

Dalam Pasal 1 Undang-undang Nomor 43 Tahun 2009 tanggal 23 Oktober 2009 tentang Kearsipan, telah didefenisikan arsip sebagai "rekaman kegiatan atau peristiwa dalam berbagai bentuk dan media sesuai dengan perkembangan teknologi informasi dan komunikasi yang dibuat dan diterima oleh lembaga negara, perusahaan, organisasi politik, organisasi kemasyarakatan, dan perorangan dalam pelaksanaan kehidupan bermasyarakat, berbangsa dan bernegara".

Menurut Burhanudin (2012: 14-15) menjelaskan arti penting arsip dalam kehidupan manusia modern secara global dapat dikelompokkan 
dalam lima bagian, yaitu: (1) kebutuhan hidup manusia sejak sebelum hidup sampai sesudah mati; Hal ini tidak dapat dipungkiri bahwa kehidupan modern menuntut ketersediaan dokumen yang menyertai kehidupan seseorang. Ketiadaan dokumen pribadi ini akan menimbulkan kesulitan bagi yang bersangkutan. Bukan hanya menyangkut identitas tetapi lebih dari itu juga menyangkut status dan hak seseorang dalam komunitasnya. Oleh karena itu, keberadaan dokumen pribadi ini seolaholah memiliki kedudukan yang sama dengan pemiliknya; (2) urat nadi bagi administrasi dan bukti kinerja; Tidak dapat dipungkiri bahwa arsip merupakan urat nadi bagi kehidupan administrasi bagi sebuah organisasi. Selain itu, arsip juga menjadi bukti kinerja sebuah organisasi. Organisasi sebagai suatu bentuk administrasi tidak mungkin mengabaikan keberadaan arsip. Setiap bentuk kegiatan mesti melahirkan arsip. Oleh karena itu, muncullah istilah arsip sebagai by product organisasi. Bagi sebuah organisasi arsip ibarat darah. Tanpa arsip sebuah organisasi akan mengalami hambatan dalam melaksanakan tugas dan fungsinya. Banyak kasus yang mencerminkan peran arsip 91 Epigram, Vol. 10 No.2 Oktober 2013:89-95 dalam sebuah organisasi; (3) Bukti dan sumber informasi otentik; Kehidupan modern yang tertumpu pada ketersediaan arsip. Status, kewenangan, hak, tanggung jawab, identitas, maupun hasil kegiatan dari suatu organisasi ataupun individu tertumpu pada arsip yang tersedia. Sebagai sumber informasi otentik karena arsip merupakan data yang tercipta paling dekat dengan kegiatan atau peristiwa yang mengiringi; (4) rekaman kegiatan/ peristiwa; Kehidupan modern yang memiliki kecanggihan teknologi yang cukup mengagumkan semakin memberi kemungkinan untuk menempatkan arsip sebagai rekaman kegiatan/peristiwa. Arsip tekstual cenderung memiliki nilai formalitas yang cukup tinggi sebagai bukti kegiatan/peristiwa tetapi arsip dalam bentuk non tekstual lebih memberi kemungkinan untuk merekam berbagai kegiatan/ peristiwa. Apalagi ada kecenderungan terjadinya peristiwa yang tidak terencana, seperti bencana alam, musibah, atau insiden lain yang tidak terencana. Kecanggihan teknologi yang kepemilikannya juga tidak 
terbatas menjadikan semakin tersedianya bukti suatu kegiatan/ peristiwa; dan (5) bukti prestasi kerja. Dalam pelaksanaan operasional organisasi, baik bisnis maupun publik, senantiasa bertumpu pada ketersediaan data.

\section{Tugas Dan Fungsi Arsiparis}

Menurut pendapat Kennedy (1998:45) Arsiparis adalah jabatan yang mempunyai ruang lingkup, tugas, tangung jawat, wewenang untuk melakukan kegiatan pengelolaan arsip dan pembinaan kearsipan yang diduduki oleh pegawai negeri sipil dengan hak dan kewajiban yang diberikan secara penuh oleh pejabat yang berwewenang.

Fungsi dan tugas Arsiparis telah tercantum dalam Pasal 151 ayat (2) Peraturan, Pemerintah Nomor 28 Tahun 2012 tentang "Pelaksanaan Undang- Undang Nomor 43 Tahun 2009 tentang Kearsipan". Untuk meemahami lebih, rinci meengenai kegiatan.kearsipan.terhadap.fungsi dan tugass sebagaimaana yang dimaksut dalam Pasal 151 ayat (2) maka, perluudiiketahuii terleebih dahulu, ruang, lingkup penngelolaan arsiptdinamistdan pengelolaantarsipsstatis. Semualfungsi,dan tugasdArsiparisgmelekattdengan lingkupzkegiatan,pengelolaanuarsip dinamisjdan pengelolaandarsip jstatis. Berikutkini kpenjabaran fungsi dan tugas Arsiparis sebagaimanalpdalam Pasal 151 ayat (2)pPeraturan Pemerintah Nomor 28 Tahun 2012, jdikaitkan dengan lingkupl kegiatan ukearsipan, tanggungjawaby dan kewenanganf yang dimilikin Arsiparisr dalam melakukanb tugas pengelolaanyoarsip dinamisx dani pengelolaanf larsipsstatis:

1. Memelihara pembuatan arsip kegiatan yang dilakukan oleh lembaga nasional, pemerintah daerah, lembaga pendidikan, perusahaan, organisasi politik, dan organisasi masyarakat. Rumusan fungsi dan tugas tersebut merupakan ruang lingkup kegiatan pembuatan dokumen. Peran arsiparis adalah untuk mengontrol semua file yang dibuat dan memulai aktivitas membuat, menerima, dan menyimpan file sedini mungkin. Arsiparis harus memahami dan menguasai teori dan praktik pengelolaan naskah dinas 
sebagai titik tolak "memelihara" arsip yang dibuat sesuai dengan standar kearsipan, baik dari segi isi, latar belakang, maupun strukturnya. Tanggung jawab pengelola arsip dalam menjalankan fungsi dan tanggung jawab ini adalah memastikan bahwa file yang dibuat di lingkungan pembuat arsip memenuhi standar arsip dengan memeriksa semua file yang dibuat. Arsiparis berhak mengetahui pembuat arsip, tampilan sistem distribusi, dan perangkat teknis lain yang menyertai pembuatan arsip. Sebagaimana dinyatakan dalam Pasal 152 a) dan b), tanggung jawab ini memberi wewenang kepada arsiparis untuk menjalankan wewenangnya untuk menutup penggunaan arsip yang menjadi tanggung jawabnya.

2. Menjaga,ketersediaan.dokumen yang otentik dan terpeercaya sebagai alat bukti yang qsah. Rumusan fungsi dan tugas tersebut adalah ruang lingkup kegiatan penggunaan dan pemeliharaan. Arsiparis memiliki fungsi menyimpan dan memelihara arsip bagi pengguna. Arsiparis pada tahap ini harus memahami dan menguasai teori dan praktek pengelolaan arsip surat, sehingga dapat menyajikan arsip secara lengkap, cepat dan lengkap pada saat dibutuhkan, sehingga arsip dapat menyajikan informasi secara kredibel. Tanggung jawab arsiparis dalam peran dan tugas ini adalah untuk memastikan bahwa file yang disajikan kepada pengguna memenuhi validitas dan keandalan, karena telah diarsipkan atau direkam sesuai dengan penggunaan alat klasifikasi file, sistem klasifikasi keamanan, dan akses ke catatan. . Prosedur. Dengan mengambil langkah-langkah untuk menyimpan dan memelihara file secara lengkap dan lengkap, arsiparis juga bertanggung jawab untuk menutup penggunaan file yang menjadi tanggung jawabnya, seperti yang dijelaskan dalam Bagian 152 (a) dan (b).

3. Pengelolaan file dan penggunaan file yang andal sesuai dengan peraturan perundang-undangan. Rumusan fungsi dan tanggung jawab tersebut merupakan ruang lingkup kegiatan kontraktor kearsipan. Tugas arsiparis adalah mengelola arsip dan menyediakan arsip yang efisien untuk kepentingan pencipta arsip dan masyarakat. Di sini, arsiparis harus menguasai teknik reduksi file dan prosedur pengarsipan penting. Alat yang digunakan adalah rencana pelestarian arsip. Tanggung jawab kearsipan 
dalam kegiatan ini adalah memastikan arsip mana yang harus dikelola oleh unit pengolah, unit kearsipan, dan organisasi kearsipan, termasuk siapa yang akan menggunakan arsip tersebut.

4. Menjaga keamanan dan perlindungan arsip, serta melindungi arsip yang berkaitan dengan hak-hak sipil rakyat melalui pengelolaan dan penggunaan arsip yang otentik dan kredibel. Perumusan fungsi dan tugas tersebut telah memasuki ruang lingkup kegiatan pengelolaan file statis, dalam hal ini memperoleh file. Tugas arsiparis adalah mengumpulkan, menyimpan, dan melestarikan arsip yang bernilai sekunder. Oleh karena itu, arsiparis harus memiliki kemampuan untuk melakukan penilaian melalui verifikasi langsung atau verifikasi tidak langsung. Arsiparis bertanggung jawab untuk memilih file yang disimpan oleh lembaga arsip. Untuk itu tugas arsiparis adalah mencari pencipta arsip sesuai dengan Pasal 152 huruf c, termasuk mencari arsip milik pencipta arsip, guna memperoleh arsip yang memiliki nilai tanggung jawab nasional dan nilai tanggung jawab nasional.mMemori kolektif bangsa.

5. Menjagamkeamanann dan pelestarian arsip sebagai bukti tanggung jawab dalam kehidupan bermasyarakat, berbangsa dan bernegara. Perumusan fungsi dan tugas ini berada dalam lingkup kegiatan pemrosesan file statis. Di sini tugas arsiparis adalah mengolah berkas-berkas tersebut agar dapat digunakan oleh publik. Arsiparis harus menguasai teknik pengolahan menggunakan alat deskripsi arsip standar, yang mengutamakan prinsip "menghormati orang lain". Pemrosesan arsip hanya untuk menunjukkan kembali informasi pembuat arsip, sebagai bukti tanggung jawab pencipta arsip kepada masyarakat, negara, dan negara atas kegiatan yang dilakukan selama ini. Oleh karena itu, arsiparis harus bertanggung jawab atas pengorganisasian arsip menurut urutan asli arsip dan asal (sumber) pencipta arsip. Berdasarkan tanggung jawabnya, tugas arsiparis adalah mencari pembuat akta sesuai dengan Pasal $152 \mathrm{c}$ ).

6. Menjaga, keamanan aset negara sebagai identitas dan jati diri bangsa di bidang ekonomi, sosial, politik, dan budaya pertahanan dan keamanan negara. Rumusan fungsi dan tugas tersebut termasuk dalam ruang lingkup 
kegiatan pelestarian arsip. Kearsipan mempunyai fungsi merawat dan memelihara arsip statis secara turun temurun, sehingga informasi dalam arsip statis dapat dikatakan sebagai aset nasional dan dapat dijadikan sebagai identitas dan jati diri bangsa. Arsiparis harus memahami pentingnya kegiatan pelestarian arsip melalui kegiatan replay dan restorasi arsip dalam rangka melestarikan arsip statis yang tersimpan dari segi informasi dan fisik arsip. Dalam konteks pelestarian arsip statis, tanggung jawab arsiparis adalah menjamin kelestarian arsip statis agar informasinya dapat digunakan sebagai identitas dan jati diri bangsa. Oleh karena itu, arsiparis memiliki tanggung jawab untuk melakukan tindakan preventif dan terapeutik terhadap informasi fisik dan arsip dalam rangka menjaga kelestarian arsip statis sebagai memori kolektif negara.

7. Memberikan informasi untuk meningkatkan kualitas pelayanan publik dalam pengelolaan dan pemanfaatan arsip yang otentik dan terpercaya. Perumusan peran dan tugas ini adalah domain dari aktivitas akses file statis. Arsiparis berperan dalam mensosialisasikan kearsipan dan pelayanan informasi arsip kepada masyarakat. Di sini, arsiparis harus memahami hak masyarakat untuk secara langsung atau tidak langsung memperoleh informasi dan teknologi layanan kearsipan. Tugas arsiparis adalah meningkatkan kualitas pelayanan publik dalam pengelolaan dan pemanfaatan kearsipan dengan menyiapkan alat bantu temu kembali arsip (seperti akses arsip), sehingga dapat memberikan informasi yang seluasluasnya kepada masyarakat.

Dari uraian diatas, fungsi dan tugas Arsiparis ini jelas-jelas memberi batasan kompetensi yang harus dikuasai dan dimiliki Arsiparis pada setiap jenjang jabatannya. Penguasaan terhadap fungsi dan tugas Arsiparis juga memberi tangungjawab kepada Arsiparis untuk mengambil segala tindakan terhadap hal-hal yang berkaitan dengan kegiatan kearsipan, dalam hal ini menjamin terselenggaranya pengelolaan arsip dinamis dan pengelolaan arsip statis, pengolahan dan penyajian arsip menjadi informasi sesuai dengan keberadaan Arsiparis dalam suatu unit kerja pada instansinya, dengan mengedepankan bahwa pekerjaan tersebut dilakukan sesuai 
standar kualitas hasil kerja Arsiparis, kaidah-kaidah kearsipan dan peraturan perundang-undangan.

\section{Lembaga Arsip Nasional Republik Indonesia}

Arsip;Nasional[ Republik/dIndonesia (ANRI) mempunyai tugas yang sangat penting dalam penyelenggaraan pemerintahan karena arsip memiliki fungsi yang sangat vital sebagai memori kolektif bangsa. Dasar hukum ANRI yaitu Undang- Undang Nomor 43 Tahun 2009 tentang kearsipan. Arsip Nasional Republik Indonesia (ANRI) berdiri di bawah koordinasi Menteri Pemberdayaan Aparatur Negara dan Reformasi Birokrasi. Melalui arsip dapat tergambarkan perjalanan sejarah bangsa dari masa ke masa.

Lembaga kearsipan di Indonesia yang beralamat di J1. Ampera Raya No. 7 RT. 3/RW.4, Kecamatan Ps. Minggu, Kota Jakarta Selatan, Ibukota Jakarta, 12560. Arsip Nasional Repubik Indonesia pada tahun 1892 ketika pemerintah Hindia Belanda mendirikan sebuah Landarchief yang bertangung jawab memelihara arsip-arsip pada masa VOC hingga masa pemerintahan hindia belanda untuk kepentingan administrasi dan ilmu pengetahuan, serta membantu melancarkan pelaksanaan pemerintah pada masa itu. Kemudian pada tahun 1942-1945 masa pendudukan jepang merupakan masa yang sepi dalam dunia kearsipan, karena pada masa itu hamper tidak mewariskan peninggalan arsip. Oleh karena itu Arsip Nasional RI tidak memiliki khazanah arsip pada masa pendudukan jepang dan berganti nama menjadi Kobunsjokan. Selanjutnya pada tahun 19451947 secara yuridis, keberadaan lembaga kearsipan Indonesia dimulai sejak diproklamasikan kemerdekaan Indonesia 17 Agustus 1945.

Setelah kemerdikaan Republik Indonesia, lemabaga kearsipan diambil oleh pemerintahan RI dan ditempatkan dalam lingkungan Kementrian Pendidikan Pengajaran dan Kebudayaan dan diberi nama Arsip Negeri. Kemudian lembaga kearsipan kembali di rebut oleh pemerintahan belanda dan diberinama Landarchief, hingga akhirnya kedaulatan pemerintah Republik Indonesia diakui oleh belanda pada akhir tahun 1949 setelah itu 
lembaga kearsipan kembali ke tangan pemerintah Indonesia dan berganti nama menjadi Arsip Negara pada tahun pada tahun 1950-1959. Kemudian berganti nama menjadi Arsip Nasional pada masa kepemimpinan Drs. R. Mohammad Ali pada tahun 1959-1967. Terakhir pada tahun 1967-sekarang menjadi Arsip Nasional Republik Indonesia yang merupakan periode yang sangat penting bagi Arsip Nasional, karena berdasarkan keputusan presiden 228/1967 tanggal 2 desember 1967, Arsip Nasional ditetapkan sebagai Lembaga Pemerintah Non Dapartemen yang bertangungjawab langsung kepada presiden. Kebijakan kea rah pemikiran untuk penyempurnaan tugas dan fungsi ANRI diwujudkan pada masa kepemimpinan Dr. Noerhadi Megatsari, yang menganti Dra. Soemartini sebagai kepala Arsip Nasional tahun 1991 hingga tahun 1998. Berikut Visi dan Misi serta Stuktur Organisasi Lembaga Arsip Nasional Republik Indonesia tahun 2021.

\section{Visi}

Visi dari Arsip Nasional Republik Indonesia adalah menjadikan arsip sebagai simpul pemersatu bangsa dalam kerangka Negara kesatuan republic Indonesia yang akan dicapai pada tahun 2025

\section{Misi}

1. Memberdayakan arsip sebagai tulang punggung manajemen pemerintah dan pembangunan

2. Memberdayakan arsip sebagai bukti akuntabilitas kinerja organisasi

3. Memerdayakan arsip sebagai alat bukti yang sah

4. Melestarikan arsip sebagai memori kolektif dan jati diri bangsa dalam kerangka Negara kesatuan republik Indonesia

5. Memberika akses arsip kepada public untuk kepentingan pemerintahan, pembangunan, penelitian, dan ilmu pengetahuan untuk kesejahteraan rakyat sesuai peraturan perundang-undangan dan kaidah-kaidah kearsipan demi kemaslahatan bangsa. 


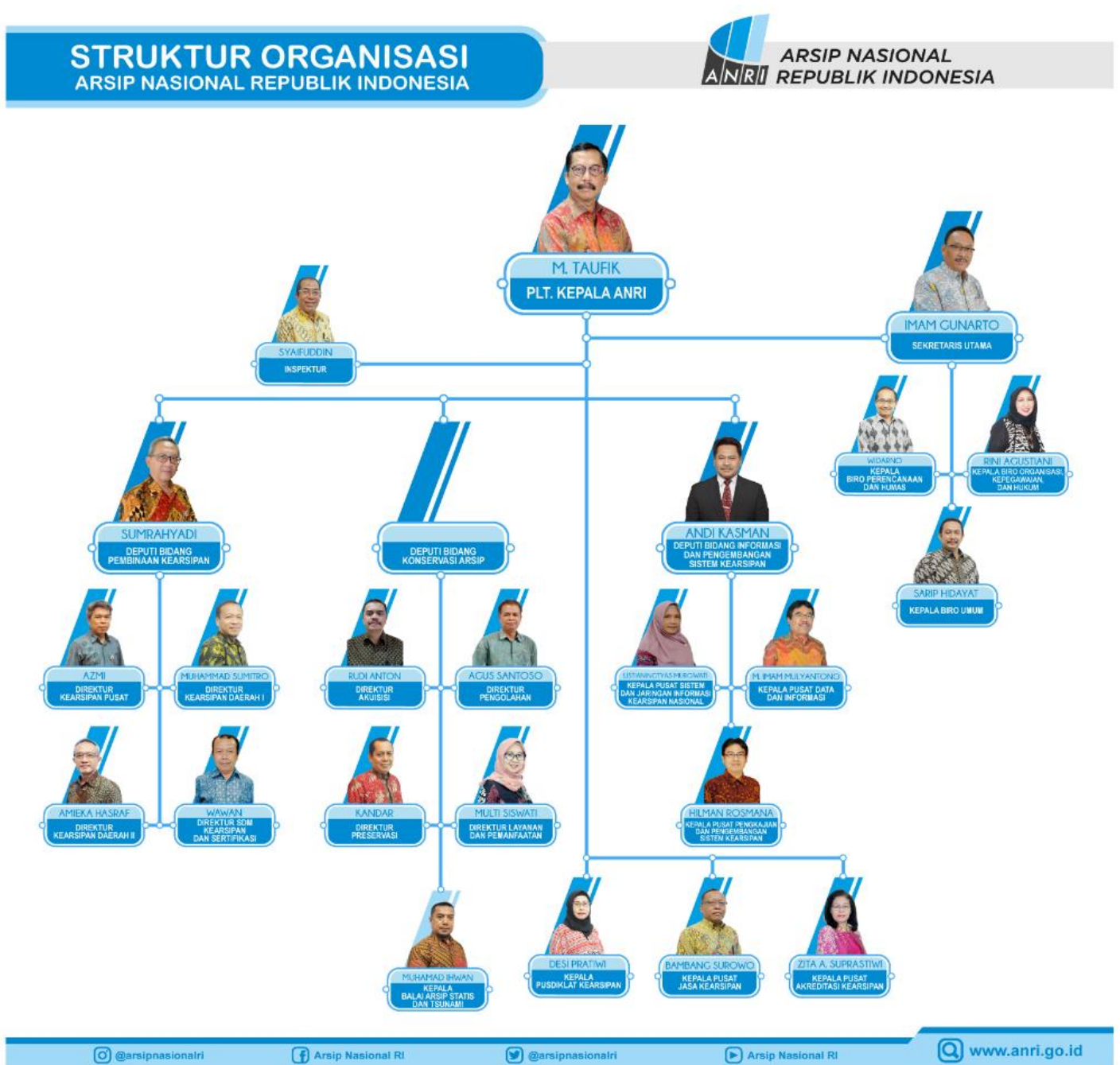

Gambar 1. Struktur Organisasi Arsip Nasional Republik Indonesia (Sumber: http://www.anri.go.id)

Kebijakan arsip nasional republik Indonesia sebagaimana diatur dalam peraturan kepala arsip nasional republik Indonesia nomor 24 tahun 2012 tentang penyelenggaraan kearsipan yakni mengatur semua kebijakankebijakan yang berkaitan dengan kearsipan nasional republic Indonesia yakni penetapan kebijakan kearsipan, pembinaan kearsipan, pengelolaan kearsipan, pengawasan dan evaluasi, kerjasama antar daerah, pembiayaan, ketentuan larangan, ketentuan sanksi,kelembagaan penyelenggara kearsipan, penataan dan penegakan hokum, ketentuan peralihan, ketentuan penutup, penjelasan. Peraturan tersebut dibuat sebagai panduan 
pemerintah daerah dalam menyusun peraturan daerah tentang kearsipan. Kemudian panduan tersebut juga dibuat dengan menampung amanat peraturan perundang-undangan bukti empiris dalam proses penyelenggaraan kearsipan di daerah yang sudah berlangsung. Dengan muatan peraturan daerah tentang kearsipan sesuai dengan kaidah kearsipan masing-masing pemerintah provinsi/kabupaten/kota maka pemerataan kualitas penyelengaaraan kearsipan pada pemerintahan daerah akan segera terwujud.

\section{Implementasi Tugas Dan Fungsi Arsiparis Sebagai Pengelola Arsip Di Lembaga Arsip Nasional Republik Indonesia}

Dalam proses pengolahan arsip di lingkungan lembaga arsip nasional Republik Indonesia, Arsiparis bertugas mengelola arsip dinamis dan arsip statis untuk menjamin ketersediaan arsip sebagai bahan akuntabilitas kinerja dan alat bukti sah dalam rangka menjaga nilai-nilai informasi yang terkandung di dalamnnya. Dalam pengolaan arsip arsiparis yang profesional di tuntut untuk bisa melaksanakan tugas pengolaan arsip dimanis mulai dari penciptaan yaitu (pembuatan, penerimaan, registrasi, pendistribusian), kemudian penggunaan dan pemeliharaan arsip yang meliputi (pemberkasan arsip aktif, penataan arsip aktif, pemeliharaan arsip, alih media arsip, dan arsip bisa digunakan), tugas yang selanjutnya yaitu proses penyusutan arsip, kegiatan ini berfungsi sebagai pengurangan jumlah arsip dengan cara pemindahan arsip inaktif dari unit penolahan ke unit kearsipan, pemusnahan arsip yang tidak bernilai guna dan penyusutan arsip dilakukan berdasarkan Jadwal retensi arsip (JRA) dengan prosedur yang harus di ikuti oleh arsiparis yaitu pemindahan arsip inaktif, pemusnahan arsip, penyerahan arsip ststis. Kemudian untuk menjaga, menyelamatkan, dan memberikan perlindungan seluruh koleksi arsip yang ada di Lembaga Arsip Nasional Republik Indonesia untuk antisipasi terjadinya hal-hal darurat atau musibah arsiparis lembaga ANRI telah melakukan program arsip Vital dengan cara melakukan identifikasi arsip, analisis hukum dan analisis resiko selanjutkan jenis-jenis arsip vital dan 
disusun daftar arsip yang ada berdasarkan metadata yaitu nama pencipta arsip, unit kerja, jenis arsip, media simpan, sarana temu kembali, volume, kurun waktu, retensi, tingkat keaslian, sifat kerahasiaan, lokasi simpan, sarana simppan dan kondisi arsip. Tugas arsiparis yang selanjutnya yaitu melaksanakan program arsip terjaga adalah tindakan dan prosedur perlindungan dan penyelamatan arsip yang berkaitan dengan masalah kependudukan, kewilayahan, kepulauan, perbatasan, perjanjian internasional, kontrak karya dan masalah pemerintahan yang strategis.

Selanjutnya arsiparis sebagai pengelola arsip juga bertugas untuk melakukan kegiatan pengolaan arsip statis diantaranya adalah melakukan aktivitas akuisisi dengan membuat pedoman akuisisi arsip statis langkah yang pertama proses Verifikasi arsip statis arsiparis harus memahami teori tentang verifikasi arsip diantaranya harus melihat nilaiguna arsip statis, yakni nilaiguna kebuktian (evidential), informational dan intrinsic. Setalah itu penerimaan arsip statis dengan membuat daftar arsip dan berita acara serah terima arsip. Tugas arsiparis selanjutnya yaitu menata informasi dan fisik arsip untuk menghasilkan sarana bantu penemuan arsip statis (finding aids). Jenis sarana bantu penemuan kembali arsip statis adalah guide arsip, daftar arsip, dan inventaris arsip. Dalam menjamin dan menjaga kelestarian arsip dibutuhkan usaha untuk mempertahankan arsip statis dalam keadaan sebaik mungkin yaitu dengan cara preservasi arsip statis (preservasi kuratif dan preservasi preventif) sehingga arsip statis dapat bertahan dalam waktu yang lama. Tugas dan fungsi arsiparis sebagai pengelola arsip selanjutnya mampu menyajikan informasi arsip kepada pengguna dan terus ditingkatkan dengan mengalihmediakan informasi arsip kebentuk digital yaitu bisa aiakses oleh siapa saja di website resmi Arsip Nasional Republik Indonesia http://www.anri.go.id untuk ketersediaan akses arsip yang dilakukan melalui prosedur yang jelas (transparan) kepada semua pengguna arsip tanpa membedakan apapun kebangsaannya, latar belakang, usia, kualifikasi atau kepentingan penelitiannya. 


\section{PENUTUP}

\section{SIMPULAN}

Berdasarkan hasil penelitian dan pembahasan dapat disimpulkan bahwa: Arsiparis Lembaga Arsip Nasional Republik Indonesia sebagai pengelola telah melaksanakan tugas yang meliputi penyelenggaraan arsip dinamis dan arsip statis yang berisi informasi dan nilai-nilai penting sebagai bukti yang autentik jika sewaktu-waktu terjadi suatu masalah. Tugas arsiparis dituntut untuk mampu menyajikan informasi arsip kepada pengguna dan terus ditingkatkan dengan mengalihmediakan informasi arsip kebentuk digital yaitu bisa akses oleh siapa saja di website resmi Arsip Nasional Republik Indonesia http://www.anri.go.id Tugas dan fungsi arsiparis sebagai pengelola arsip meliputi penciptaaan arsip penciptaan yaitu (pembuatan, penerimaan, registrasi, pendistribusian), kemudian penggunaan dan pemeliharaan arsip yang meliputi (pemberkasan arsip aktif, penataan arsip aktif, pemeliharaan arsip, alih media arsip, dan arsip bisa digunakan), penyusutan arsip, pemusnahan arsip yang tidak bernilai guna dan penyusutan arsip dilakukan berdasarkan Jadwal retensi arsip (JRA) dengan prosedur yang harus di ikuti oleh arsiparis yaitu pemindahan arsip inaktif, pemusnahan arsip, penyerahan arsip statis, akuisisi arsip, finding aids, jenis sarana bantu penemuan kembali arsip statis adalah guide arsip, daftar arsip, dan inventaris arsip. Dengan demikian arsiparis di lembaga arsip nasional Republik Indonesia telah mengimplmentasikan tugas dan fungsinya sebagai arsiparis yang sesuai dengan .Pasal 151 (2), Peraturanl iPemerintah Nomorp 28 Tahun 2012 mengatur tentang pelaksanaan UU Kearsipan Nomor 43 Tahun 2009. 


\section{DAFTAR PUSTAKA}

Barthos, B. 2012. Manajemen Kearsipan Untuk Lembaga Negara, Swasta, dan Perguruan Tinggi. Cetakan Ke-8. PT Bumi Aksara, Jakarta.

Burhanudin, D.R. 2012. Peran dan Profesionalisme Asparis. Khazanah Buletin Kearsipan. Vo. 5, No.1, Maret : $11-27$

Kennedy, Jay (\&), Schauder, Cherryl (1998) Manajemen Arsip; pedoman untuk menyimpan catatan perusahaan. Australia: Addison Wesley Longman Lexxy J. Moleong. 2019 Metodologi Penelitian Kualitatif. Bandung: PT. Remaja Rosdakarya

Peraturan Kepala Arsip Nasional Republik Indonesia Nomor 24 Tahun 2011 Tentang Pedoman penyelenggaraan kearsipan di lingkungsn perguruan tinggi

Sugiyono. 2007. Metode Penelitian Kuantitatif Kualitatif dan $R \& D$. Bandung: Alfabeta

Undang-Undang Nomor 43 Tahun 2009 tentang Kearsipan Peraturan Menteri Pendayagunaan Aparatur Negara dan Reformasi Birokrasi

Undang-Undang Nomor 43 Tahun 2009 tentang KearsipanPeraturanNPemerintahP NomorR28 Tahun, 2012 tentangEPelaksanaanS

Undang-UndangONomorL48, Tahun.2014 tentangL JabatanI FungsionalTArsiparis' sebagaimanaLtelah Sdiubah Qdengan aPeraturan ;Menteri oPendayagunaan Aparaturw iNegara dan 1Reformasi Birokrasil Nomori 13 Tahun 20160

Undang-Undang Republik Indonesia Nomor 43 Tahun 2009 tentang kearsipan diakses www.kkp.go.id 